\title{
AGUSTUS VERSUS KRISTUS DI SURAT FILIPI (BAGIAN 2): Pembacaan Anti-Imperial terhadap Filipi 2:6-11
}

\begin{abstract}
Surif*
Abstrak: Artikel ini adalah kelanjutan dari artikel sebelumnya dengan judul yang sama. Tesis yang ditawarkan adalah bahwa Filipi 2:6-11 adalah narasi Injil Yesus Kristus dan perlu dipahami di dalam konteks konfrontasi teologis-ideologis terhadap injil Kaisar Agustus yang semarak dipropagandakan otoritas Romawi di banyak wilayah kekuasaan Romawi, termasuk di kota koloni Romawi Filipi, pada masa itu. Di dalam kerangka ini, Yesus Kristus digambarkan sebagai antitesis dari figur Agustus, kaisar terbesar Romawi pada saat itu. Narasi Injil Kristus di dalam Filipi 2:6-11 mengklaim sebagai berikut. Pertama Yesuslah, dan bukan Agustus, yang berstatus Ilahi (ay. 6) yang sesungguhnya karena karya pelayanan-Nya bagi semua umat manusia (ay. 7-8). Kedua, Yesuslah, dan bukan Agustus, yang ditinggikan oleh Allah sebagai Tuhan atas semesta (ay. 9). Ketiga, pada akhirnya Yesuslah, dan bukan Agustus, yang akan disembah sebagai Tuhan oleh seluruh ciptaan (ay. 10-11). Pembacaan yang demikian akan memberikan perspektif baru bagi pemahaman pergumulan jemaat Kristus di Filipi maupun bagi pemahaman atas berbagai nasihat Paulus yang tercantum di dalam surat Filipi.
\end{abstract}

Abstract: This article is the continuation of the previous article "Augustus Versus Christ in Philippians." It is proposed in this second article that Philippians 2:6-11 is a narratival gospel of Jesus Christ, and it needs to be understood in the context of Paul's theological and ideological confrontation with the gospel of Caesar Augustus that had been popularly propagated at that time by the imperial authority in many parts of Roman empire, including in the Roman colonial city of Philippi. In this framework, it is argued that

* Penulis adalah dosen Biblika di Sekolah Tinggi Teologi Amanat Agung. Penulis dapat dihubungi melalui email: surif@sttaa.ac.id. 
Philippians 2:6-11 portrays Jesus Christ as the antithesis of Augustus, the greatest Roman Caesar at that time. This narratival gospel makes claims as follows. First, it is Jesus, and not Caesar Augustus, who is the real divine (v. 6) on account of his benefactional minisrty to all humankind (vv. 7-8). Second, it is Jesus, and not Caesar Augustus, who has been highly exalted by God himself as the lord of the whole universe (v. 9). Third, at the end, it is Jesus, and not Caesar Augustus, who will be worshiped as the Lord by the all creatures (vv. 10-11). This reading will give us a better understanding on the struggle of the Philippians church, and thus on Paul's paranesis in his letter to this church.

Kata-kata Kunci: Surat Filipi, Paulus, Agustus, Kristologi, Injil, Anti - Imperialisme.

\section{Pendahuluan}

Dalam artikel yang pertama, penulis telah menjabarkan bagaimana kultus Kaisar ${ }^{1}$ Agustus telah berkontribusi di dalam membangkitkan sentimen negatif masyarakat imperial di Filipi terhadap para pengikut Yesus Kristus di kota itu. Mereka menolak ikut serta di dalam berbagai pemujaan dewa Agustus demi iman mereka kepada Kristus Yesus. Tindakan ini membuat mereka dianggap tidak loyal kepada otoritas Romawi karena mengganggu stabilitas Pax Deorum dan Pax Romana yang dibangun oleh Kaisar

1. Dalam makalah ini, kata Kaisar tidak diartikan sebagai maharaja (arti menurut KBBI V), karena sistem pemerintahan Romawi tidak mengenal posisi raja. Pada awalnya Kaisar adalah panggilan dari tokoh Yulius Kaisar. Dalam perkembangannya, kata ini disandingkan kepada Agustus sebagai titel kehormatan. Sejak saat itu, semua imperator Romawi disandingkan titel Kaisar. 
Agustus. Akibatnya, umat Kristen di Filipi menderita berbagai tekanan dari masyarakat dan otoritas imperial Romawi.

Merespons pergumulan jemaat Kristus di Filipi, Paulus menggambarkan Kristus Yesus di dalam Filipi 2:6-11 untuk mendorong mereka tetap teguh berdiri di atas pengakuan iman mereka (Flp. 1:27-30). Di dalam perspektif ini, perikop ini dapat dilihat sebagai narasi Injil Yesus Kristus yang mengkritik narasi injil Agustus yang dipropagandakan oleh otoritas imperial Romawi di seluruh teritori kekuasaannya pada zaman Paulus. Untuk mendukung tesis ini, penulis akan membagi pembahasan di dalam makalah ini ke dalam tiga bagian. Bagian pertama berargumentasi bahwa surat Filipi memiliki karakter anti-imperial. Bagian kedua membangun asumsi bahwa sangat mungkin Injil Kristus di Filipi 2:6-11 merespons kepada injil Agustus yang saat itu populer di kekaisaran Romawi. Bagian terakhir menghadirkan pembacaan Filipi 2:6-11 yang merespons narasi injil Agustus.

\section{Karakter Anti-Imperial dari Surat Filipi}

Penafsiran Filipi 2:6-11 di dalam makalah ini didasarkan pada pandangan bahwa isi surat Filipi mengandung pemikiran antiimperial. Karena isu karakter anti-imperial dari surat-surat Paulus masih diperdebatkan hingga kini, ${ }^{2}$ bagian ini akan memaparkan berbagai argumen pendukung atas pandangan ini.

2. Perdebatan ini terlihat pada perdebatan antara N. T. Wright dan John M. G. Barclay. Kritik Barclay atas anti-imperial reading of Paul dari N. T. 
Surat Filipi jelas mengandung berbagai ekspresi yang dapat diasosiasikan dengan kekuasaan imperial Romawi. Pertama, dalam surat ini ada berbagai kata yang sering dipakai dalam propaganda

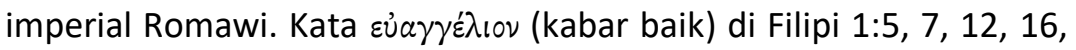

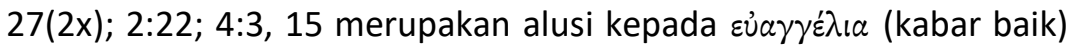

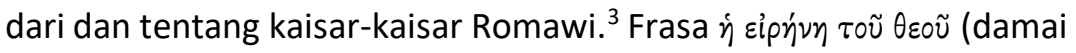
dari Allah) di Filipi 4:7 mengingatkan pembaca akan jargon $\dot{\eta}$ Eipŕvn $\tau \tilde{\omega} \nu$ $\theta \varepsilon \tilde{\omega} \nu$ atau Pax-Deorum (damai dari para dewa) yang erat kaitannya dengan ideologi imperial Pax-Romana. ${ }^{4}$ Surat Filipi juga memakai berbagai terminologi kolonial. Pada Filipi 4:15, Paulus memanggil jemaat di Filipi tidak dengan sebutan $\Phi_{\iota} \lambda \iota \pi \pi \circ$ yang menekankan kepada kesukuan, tetapi dengan sebutan $\Phi_{\iota} \lambda \iota \pi \pi \eta \sigma o l$ (Latin: Philippensis) yang merujuk kepada nama formal dari koloni

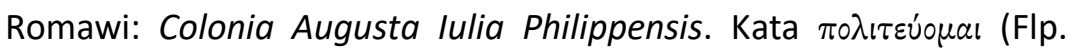
1:27) dan $\pi \circ \lambda i \tau \varepsilon v \mu \alpha$ (Flp. 3:20) juga berasosiasi kuat dengan status Filipi sebagai koloni atau bagian dari persemakmuran kekaisaran

Wright dimuat di dalam bukunya Pauline Churches and Diaspora Jews, WUNT 275 (Tubingen: Mohr Siebeck, 2011), pada bab 18-19. Kritik ini kemudian direspons kembali oleh Wright di dalam bukunya Paul and the Faithfulness of God (Minneapolis: Fortress, 2013), pada bab 5 dan 12.

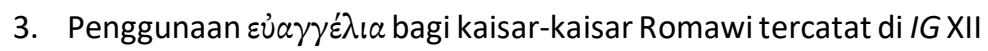
Supp.124; Philo, Legat. 18, 22, 99, 231; Josephus, Jewish War IV. 618; Priene Calendar Inscription (OGIS II, 458).

4. Pencapaian Pax-Deorum versi kekaisaran Romawi dideklarasikan melalui pembangunan monumen Ara Pacis Augustae di campus Martinus di Roma pada tahun 13-9 SM. 
Romawi. Di Filipi 2:25, Paulus memanggil Epafroditus sebagai

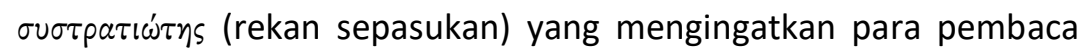
akan latar belakang militer dari koloni ini. Selanjutnya, titel xúpıs (Tuhan) di Filipi 2:11 dan 3:20 dan $\sigma \omega \tau \eta \dot{p}$ (Penyelamat) di Filipi 3:20 yang disandingkan kepada Yesus ternyata juga merupakan titel penghormatan yang diberikan kepada para kaisar Romawi. ${ }^{5}$ Akhirnya, ada berbagai gambaran imperial di dalam surat Filipi.

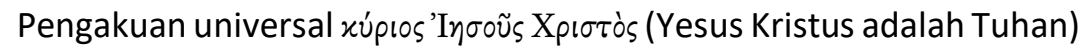
di Filipi 2:11 mirip dengan teriakan xúpıos Kaĩoap (Kaisar adalah Tuhan) pada prosesi penyambutan kaisar Romawi dan ritual sumpah di

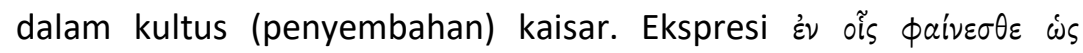
$\phi \omega \sigma \tau \tilde{p} \rho \varepsilon \varsigma$ ह̇v xó $\sigma \mu \omega$ (di dalamnya kamu bersinar sebagai terang di dunia) di Filipi 2:15 mirip dengan peran koloni Romawi di Filipi, yakni menghadirkan terang dan kekuasaan Romawi di tanah Makedonia. ${ }^{6}$

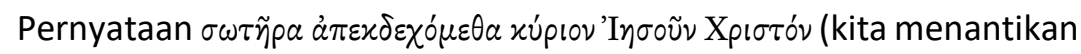
Penyelamat, Tuhan Yesus Kristus) analog dengan seruan kepada penduduk koloni di diaspora yang menantikan kedatangan ( $\pi \alpha \rho \circ \sigma^{\prime} \alpha$ )

5. Penyandingan gelar xúplos tercatat di BGU, 1197.1.15; Ditt. Or. 606; P. Oxy. 1.37.5f; Ditt. Syll. 3.814.31. Lihat Foerster, "xúplos," TDNT

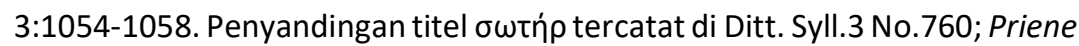
Calendar Inscription (OGIS II, 458); Philo, Legat. 22; IGRR IV, 12 dan IGRR IV, 584. Lihat Foerster, " $\sigma \omega \tau \dot{\rho} \rho, "$ TDNT 7:1010-1012.

6. Christopher Bryan, Render to Caesar: Jesus, the Early Church, and Roman Superpower (Oxford: Oxford University Press, 2005), 84. 
Kaisar Romawi beserta dengan pasukannya yang akan menyelamatkan mereka dari ancaman musuh. ${ }^{7}$

Di sisi lain, tidak dapat dipungkiri bahwa berbagai ekspresi imperial tersebut juga berakar di dalam kitab suci orang Yahudi, terutama dalam terjemahan Yunani yang dikenal dengan LXX.

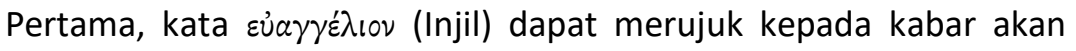
kedatangan keselamatan eskatologis dari Yhwh yang disuarakan

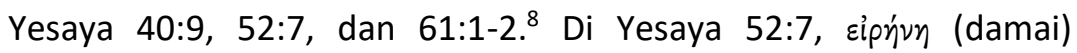

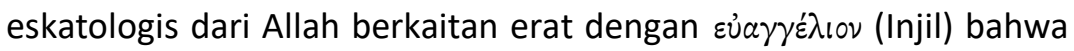
Yhwh sekarang memerintah di Sion. Kedua, penyandingan kata xúpıs (Tuhan) kepada Yesus Kristus memiliki makna teologis, karena di LXX kata ini dipakai sebagai referensi pengganti dari Tetragammaton, Yhwh. Demikian juga, kata $\sigma \omega \tau \eta \dot{p}$ (Penyelamat) sering dipakai di LXX (Mzm. 24:5; 26:1, 9; 61:3, 7; 64:6; 78:9 dan Yes. 12:2; 45:15, 21; 62:11) untuk menggambarkan Allah yang menyelamatkan. Analogi cahaya di Filipi 2:15 dapat dilihat sebagai gaung dari metafora cahaya di Yesaya 9:2, 42:6, 49:6, 60:3 atau pun di Daniel 12:3.

Dua kenyataan ini melahirkan satu pertanyaan penting di dalam pemahaman surat Filipi: apakah Paulus menggunakan berbagai ekspresi yang berkonotasi pada imperial Romawi secara

7. N. T. Wright, "Paul's Gospel and Caesar's Empire," dalam Paul and Politics: Ekklesia, Israel, Imperium, Interpretation, ed. Richard A. Horsley (Harrisburg: Trinity Press International, 2000), 173-174.

8. James D. G. Dunn, The Theology of Paul the Apostle (Grand Rapids: Eerdmans, 1998), 167-68; kontra Graham Stanton, The Gospels and Jesus, ed. ke-2 (New York: Oxford University Press, 2002), 19-20. 
analogis-akomodatif ${ }^{9}$ atau secara polemik-konfrontatif? ${ }^{10}$ Studi ini menekankan pada cara yang kedua dengan berbagai alasan berikut ini.

Pertama, deskripsi mengenai dirinya yang sedang menderita di dalam penjara Romawi di Filipi 1:12-26 dan 30 mengindikasikan adanya konflik antara otoritas imperial Romawi dan Paulus di dalam konteks pewartaan Injil Kristus. Walaupun di dalam berbagai suratnya tidak ada indikasi yang menunjukkan Paulus berkeinginan menghancurkan kekuasaan Romawi, ketika kekaisaran Romawi menolak dan menghalangi pewartaan Injil Kristus, maka tidak ada respons yang bersifat kompromi dari Paulus yang hasrat terbesarnya

9. Christopher Bryan, Render to Caesar; Seyoon Kim, Christ and Caesar: The Gospel and the Roman Empire in the Writings of Paul and Luke (Grand Rapids: Eerdman, 2008); Lynn H. Cohick, "Philippians and Empire: Paul's Engagement with Imperialism and the Imperial Cult," dalam Jesus is Lord and Caesar is not: Evaluating Empire in New Testament (Downers Grove: IVP Academic, 2013), 166-81.

10. Dieter Georgi, Theocracy in Paul's Praxis and Theology, terj. D. E. Green (Minneapolis: Fortress, 1991), 72-78; David Seeley, "The Background of the Philippians Hymn (2:6-11)," Journal of Higher Criticism 1 Fall (1994): 49-72; Adela Yarbro Collins, "The Worship of Jesus and the Imperial Cult," dalam The Jewish Roots of Christological Monotheism: Papers from the St. Andrews Conference on the Historical Origins of the Worship of Jesus, SJSJ 63 (Leiden: Brill, 1999), 234-57; Wright, "Paul's Gospel and Caesar's Empire," 160-83; Peter Oakes, "Re-mapping the Universe," JSNT 27.3 (2005): 301-22; Richard J. Cassidy, Paul in Chains: Roman Imprisonment and the Letters of St. Paul (New York: The Crossroad, 2001), 178-84; Erik M. Heen, "Phil. 2:611 and Resistance to Local Timocratic Rule: Isa theo and the Cult of the Emperor in the East," dalam Paul and the Roman Imperial Order (Harrisburg: Trinity Press International, 2004), 125-54; Norman A. Beck, Anti-Roman Cryptograms in the New Testament: Hidden Transcripts of Hope and Liberation, edisi revisi, SBL 127 (New York: Peter Lang, 2010), 47-61. 
adalah membesarkan Kristus dan mewartakan Injil-Nya (Flp. 1:18, 20).

Kedua, sebagai rekan seperjuangan di dalam Injil Kristus, jemaat di Filipi juga menghadapi berbagai tekanan dari masyarakat dan otoritas imperial di kota ini. Panggilan untuk berdiri teguh bersama-sama bagi Injil Kristus di Filipi 1:27 dan 4:1 perlu dilihat sebagai respons Paulus yang bersifat konfrontatif terhadap tekanan dari masyarakat imperial di Filipi.

Ketiga, penganiayaan yang dialami jemaat Kristus di Filipi tidaklah disebabkan oleh pengamalan etika Kristen tetapi lebih dikarenakan oleh konfrontasi orientasi penyembahan. Mayoritas pengikut Kristus di Filipi bukan berasal dari kalangan Yahudi. Untuk mendedikasikan diri mereka secara penuh kepada penyembahan kepada Yhwh dan Kristus Yesus, mereka telah meninggalkan segala praktik religius yang lama, termasuk kultus kepada kaisar Romawi yang semarak di kota itu. Ketidaksertaan di dalam kultus imperial ini, terutama dewa Kaisar Agustus, telah membangkitkan sentimen negatif dari masyarakat imperial di Filipi.

Christopher Bryan menolak adanya pemikiran anti-imperial di dalam surat Filipi karena tidak adanya pernyataan eksplisit yang menentang otoritas Romawi di dalam surat ini. ${ }^{11}$ Menurutnya, penggunaan terminologi yang diklaim bermuatan imperial terbentuk oleh penggunaan teknik penafsiran midrash qal va-chomer (dari hal yang ringan ke hal yang berat). Di dalam perspektif ini, dia

11. Bryan, Render to Caesar, 84, 87. 
berargumen "... if the Philippians know what might be due from them and to them rarely as citizens of Rome, then by how much more they should know what is due from them and to them as citizens of a realm whose emperor is lord of lords and king of kings." ${ }^{12}$ Selanjutnya, ia juga berargumentasi bahwa berbagai perikop yang bernada imperial (Flp. 1:27-30; 2:6-11; 3:18-21) tidak berfungsi untuk mengkonfrontasi kekuasan imperial Romawi, tetapi menyelesaikan masalah internal jemaat Kristus (Flp. 2:2-4, 12-14; 4:2-3). ${ }^{13}$

Merespons penolakan ini, pembahasan di dalam makalah ini mengerucut kepada kesimpulan yang berbeda. Walaupun argumen pertama cukup beralasan, ini tidak serta merta mengeliminasi karakter anti-imperial dari pernyataan Paulus. Kontekslah yang lebih menentukan apakah pernyataan Paulus bernuansa polemik atau tidak. Analisis berikut ini mendemonstrasikan kelemahan dari argumen kedua dari Bryan.

Pertama, penekanan Bryan bahwa perhatian utama dari pernyataan Paulus di Filipi 1:27-30; 2:1-4; 2:12-18, dan 3:20-4:3 adalah pada kesatuan jemaat terlampau menyederhanakan kompleksitas permasalahan jemaat Kristus di Filipi, karena kurang mengapresiasi keterlibatan kekuasaan imperial di dalam penindasan jemaat ini sebagai latar belakang dari perintah Paulus untuk bersatu hati di 2:1-4. Sangat mungkin panggilan untuk berdiri teguh di dalam kesatuan bagi iman dari Injil Kristus di 1:27-30 berkarakter anti-

12. Bryan, Render to Caesar, 84.

13. Bryan, Render to Caesar, 84-90. 
imperial, karena ini adalah merespons terhadap tekanan ekonomi dan sosial dari masyarakat imperial Romawi di kota Filipi.

Kedua, paraklesis di Filipi 2:12-16 juga perlu diletakkan pada konteks pergumulan pengikut Kristus di tengah $\gamma \varepsilon v \varepsilon a \tilde{s} \sigma$ $\sigma 0 \lambda i \tilde{a} s$ xaì

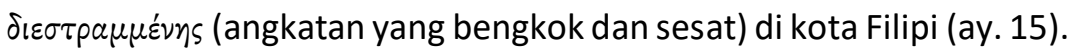
Frasa ini merupakan alusi kepada Keluaran 32:5, sehingga berkonotasi pada penyembahan berhala, termasuk kultus para kaisar Romawi. Ketika membaca Filipi 2:6-11, jemaat di kota ini dengan mudah merasakan ketegangan antara pengakuan "Yesus Kristus adalah Tuhan ( $x$ úplos)" di 2:11 dan pengakuan "kaisar adalah Tuhan (xúplos)" di dalam berbagai kultus kaisar Romawi. Dengan demikian, panggilan berdiri teguh di dalam kesatuan di Filipi 1:27-30 perlu dilihat di dalam konteks penolakan kepada penyembahan kepada kaisar Romawi demi penyembahan kepada Kristus (Filipi 2:10-11).

Ketiga, dorongan Paulus $\sigma \tau \eta^{\prime} x \varepsilon \tau \varepsilon$ ह̇v xupị́ (Tetaplah berdiri teguh di dalam Tuhan) di Filipi 4:1 tidak hanya terhubung dengan

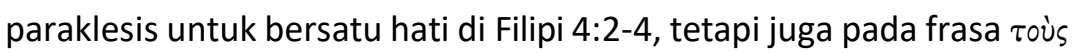

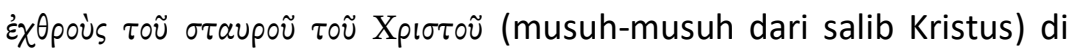
Filipi 3:18-19. Untuk menghindar dari tekanan dan penindasan dari masyarakat imperial Romawi, beberapa pengikut Kristus telah melepaskan iman mereka. Merespons keadaan ini Paulus mendorong jemaat di Filipi untuk tetap berdiri teguh di dalam Tuhan melalui pengharapan eskatologis bahwa Yesus Kristus, bukan kaisar Romawi, 
adalah Tuhan yang akan menyelamatkan mereka dengan kuasa-Nya (Flp. 3:20-21).

Ketiga analisis di atas mendemonstrasikan bahwa pernyataan Paulus di suratnya kepada jemaat di Filipi sangat mungkin berpolemik untuk mengonter kekuatan imperial Romawi. Walaupun Paulus tidak bermaksud untuk menjatuhkan kekaisaran Romawi, penderitaannya di dalam perkabaran Injil Kristus dan penderitaan jemaat Kristus di kota Filipi akibat tekanan kekuasaan imperial membuat dia merasa perlu mengonter kekuatan imperial Romawi di dalam suratnya demi kemajuan Injil Kristus.

\section{Injil Kristus Versus Injil Agustus}

Terlepas apakah Filipi 2:6-11 berbentuk himne, puisi, prosa, encomium, atau himnos, secara konten perikop ini dapat disebut sebagai Injil Yesus Kristus yang berbentuk narasi. Pertama, secara umum para ahli mengakui karakter naratif dari Filipi 2:6-11. ${ }^{14}$ Perikop ini memiliki aktor, yakni Yesus (ay. 6-8), Bapa (ay. 9), dan seluruh ciptaan (ay. 10-11). Selanjutnya, perikop ini menjabarkan peristiwa

14. Gordon D. Fee, Paul's Letter to the Philippians, NICNT (Grand Rapids: Eerdmans, 1995), 193-94; Joseph H. Hellerman, Reconstructing Honor in Roman Philippi: Carmen Christi as Cursus Pudorum, SNTSMS 132 (Cambridge: Cambridge University Press, 2005), 130; Michael J. Gorman, Inhabiting the Cruciform God: Kenosis, Justification, and Theosis in Paul's Narrative Soteriology (Grand Rapids: Eerdmans, 2009), 13-17. Menurut Mark Allan Powell, What is Narrative Criticism? (Minneapolis: Fortress, 1990), 35, "every story generally encompasses three elements: events, characters and setting. We may also add the plot that interpretatively describes the action and movement in the story." 
secara kronologis, seperti inkarnasi (ay. 7), kematian di kayu salib (ay. 8), kebangkitan dan kenaikan (ay. 9), dan kedatangan Kristus sebagai Raja (ay. 10-11). ${ }^{15}$ Akhirnya, perikop ini memiliki pergerakan, ${ }^{16}$ yakni dengan plot " $\mathrm{U}$ ", atau "V" (absement-exaltation) yang merupakan ciri narasi komedi. Semua ini mengindikasikan bahwa walaupun sangat pendek, perikop ini dapat dikategorikan sebagai sebuah narasi.

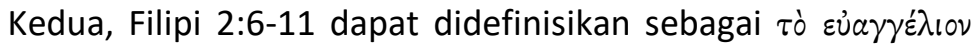
(Injil) tentang Yesus Kristus. Walaupun, kata ini tidak muncul, relative

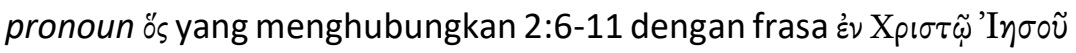
(di dalam Kristus Yesus) di akhir ayat 5 mengindikasikan bahwa perikop ini menjabarkan Yesus Kristus dalam bentuk narasi.

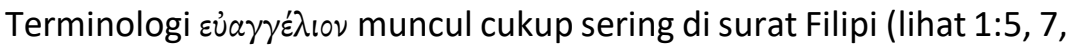
$16,27(2 x) ; 2: 22 ; 4: 3,15)$ dan merupakan tema penting di surat ini.

15. Ayat 9-11 menggambarkan dua peristiwa yang berbeda: (1) kebangkitan dan kematian Kristus di ayat 9 dan (2) kedatangan-Nya sebagai Tuhan atas segala tuan di ayat 10-11. Lihat Fee, Philippians, 220, 223; Martin, Philippians (2004), 125-131; Bockmuehl, Philippians, 140-41, 146. Takeshi Nagata, "Philippians 2:5-11: A Case Study in the Contextual Shaping of Early Christianity" (disertasi PhD., Princeton Theological Seminary, 1981), 284-285, yang membaca ayat 9-11 hanya sebagai satu peristiwa, yakni kebangkitan-kenaikan Kristus.

16. Kata kerja yívouaı di ayat 6-8 lebih menunjukkan suatu aktivitas

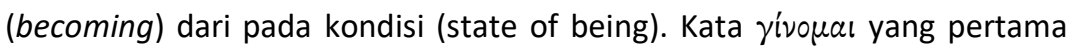
merujuk kepada inkarnasi Kristus (Rm. 1:3 dan Gal. 4:4), kata yang kedua merujuk kepada kematian-Nya di atas kayu salib. Konjugasi diò xaí dan struktur iva + subjungtif di ayat 9-11 juga menujukkan progres yang kronologis. Lihat BDAG, 198 (poin 5c); bandingkan Richard B. Hays, The Faith of Jesus Christ: the Narrative Substructure of Galatians 3:1-4:11, edisi ke-2 (Grand Rapids: Eerdmans, 1997), 96-97. 
Karena persekutuan antara Paulus dan para pembaca surat Filipi adalah dalam Injil Yesus Kristus (Flp. 1:5), Paulus mendorong mereka untuk terus hidup bermartabat sesuai dengan Injil ini (Flp. 1:27). Perintah ini mengantisipasi narasi Injil di Filipi 2:6-11. Jika Injil Kristus di Roma 1:3-4 dan 1 Korintus 15:3-4 hanya menjabarkan kematian dan kebangkitan-Nya, maka di Filipi 2:6-11 Injil Kristus dijabarkan secara lebih lengkap, yakni mencakup status awal Kristus (ay. 6), inkarnasi-Nya (ay. 7), penderitaan dan kematian-Nya (ay. 8), kebangkitan dan kenaikan-Nya (ay. 9), and kedatangan-Nya kembali. (ay. 10-11).

Adalah tesis makalah ini bahwa narasi Injil Kristus di Filipi 2:611 mempresentasikan Yesus sebagai figur anti-tesis dari Agustus, kaisar terbesar di dalam sejarah Romawi. Pandangan ini didukung oleh penggunaan berbagai ekspresi imperial yang berkaitan erat dengan kaisar Romawi, tetapi diaplikasikan justru kepada Yesus Kristus.

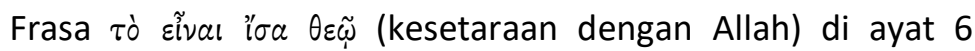

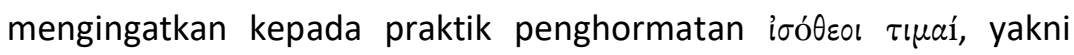
penghormatan yang setara dengan para dewa, kepada kaisar

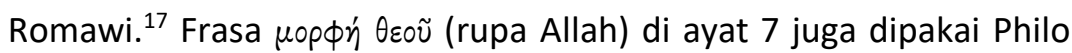
dalam mengkritik kaisar Caligula yang mengklaim dirinya sebagai penjelmaan dewa (Apollo) dengan cara berpakaian seperti dewa ini. ${ }^{18}$

17. Heen, "Phil 2:6-11," 82-83, 125-36.

18. Philo, Legat, 110. 
Selanjutnya, pengakuan pujian xúpıos 'Inбoũs Xpırtós (Yesus Kristus adalah Tuhan) di ayat 10-11 mirip dengan penghormatan imperial xúpıos Kaĩ aap (kaisar adalah Tuhan). Dengan mempertimbangkan bahwa pergumulan Paulus dan jemaat Kristus di Filipi di bawah tekanan otoritas imperial Romawi (1:7, 12, 27-30), sangatlah mungkin bahwa injil Kristus di 2:6-11 bertujuan untuk mengkritik public imperial discourses di kota Filipi yang terus mempropagandakan kebesaran, keilahian, dan penyembahan kaisar Romawi.

Perspektif ini dapat dipertajam dengan rekonstruksi bahwa narasi Injil Kristus di Filipi 2:6-11 juga ditulis untuk mengonter narasi imperial Dewa Kaisar Agustus. Pertama, hingga surat ini ditulis hanya ada empat figur imperial yang secara formal didewakan oleh Senat di Roma, yakni Kaisar Yulius, Kaisar Agustus, Livia yang adalah istri Agustus, dan Kaisar Klaudius. Dari keempat kandidat ini, figur Agustuslah yang paling mungkin, karena dia dianggap sebagai kaisar terbesar Romawi yang dikagumi dan diteladani. ${ }^{19}$

19. Pada saat itu Kaligula telah menerima pernyataan kutukan secara formal dari Senat Roma. Nero masih memerintah sehingga belum didewakan. Klaudius telah didewakan, tetapi kultus dirinya kurang di masyarakat Romawi populer karena kekejamannya selama dia memerintah. Livia (istri Agustus) juga telah didewakan dan kultus dirinya memang popular di Filipi, tetapi dia adalah figur wanita. Dengan demikian, figur yang tertinggal hanyalah Yulius dan Agustus. Di antara keduanya, Agustus menjadi kandidat terbaik, karena dialah yang berhasil membangun Pax Romana. 
Kedua, koloni Romawi di Filipi memiliki ikatan yang kuat dengan tokoh ini. Koloni ini berhutang-budi kepada Kaisar Agustus, sehingga dia dipandang sebagai patron dewa yang dipuja dan disembah secara semarak. Di kota ini Agustus juga diasosiasikan dengan dewa Mercurius, anak dari dewa Yupiter. ${ }^{20}$ Dengan demikian, klaim bahwa Kristus sebagai Anak dari Sang Bapa di Filipi 2:11 mengingatkan para pembaca kepada klaim imperial akan Agustus sebagai anak dewa Jupiter. ${ }^{21}$

Ketiga, kultus Agustus adalah kultus kaisar Romawi yang paling populer dalam kekaisaran Romawi di masa itu. Berbagai penemuan arkeologis dan inskripsi yang mengindikasikan popularitas kultus ini di provinsi Yunani, Makedonia, dan Asia. ${ }^{22}$ Paulus, seorang misionaris yang menjelajahi kawasan ini, jelas menyaksikan maraknya propaganda imperial akan Kaisar Agustus berikut dengan popularitas kultus dirinya. ${ }^{23}$ Dua inskripsi yang merupakan public imperial discourses tentang Augustus di provinsi Asia perlu dipertimbangan sebagai latar belakang dari narasi Injil Kristus di Filipi 2:6-11.

Inskripsi pertama adalah kalender di provinsi Asia yang ditulis pada tahun 9 SM. Salinan inskripsi ini dalam bahasa Yunani terukir di

20. Lihat inskripsi no. 250 dalam Peter Pilhofer, Philippi Band 2: Katalog der Inschriften von Philippi. 2 (WUNT 119; Tübingen: Mohr Siebeck), 2009.

21. Kedekatan hubungan Agustus dengan dewa Jupiter tercatat dalam Ovid, Metamorphoses 15.858-59.

22. Stanley E. Porter, "Paul Confronts Caesar with the Good News" dalam Empire in the New Testament (Eugene: Wipf \& Stock, 2011), 172-173.

23. Porter, "Paul Confronts Caesar with the Good News," 173-174. 
ruang publik kota Priene, Apamea Kobotos, Maionia, dan Eurmenia, dan salinan inskripsi ini dalam bahasa Latin ada di kota Apamea Kobotos dan Dorylaion. Paulus sangat mungkin melihat inskripsi kalender berbahasa Yunani ketika tinggal di Efesus (Kis. 19:10) yang letaknya berdekatan dengan kota Priene. Dalam inskripsi ini, Agustus dipuja sebagai juru selamat dunia dan the greatest benefactor bagi dunia. Dia bahkan diklaim sebagai utusan dewa yang kelahirannya ditetapkan oleh instalasi bintang-bintang di angkasa. Itu sebabnya tanggal kelahirannya dideklarasikan sebagai permulaan dari semua kabar baik.

Inskripsi kedua adalah Res Gestae Divi Augusti (RGDA) yang ditulis oleh Kaisar Agustus sendiri. Tulisan ini dibaca di dalam rapat Senat Roma sesaat sesudah kematiannya di tahun $14 \mathrm{M}$, dan diukir kembali pada lempengan perunggu di dinding Mausoleum dirinya di Campus Martius. Tulisan RGDA ini memiliki berbagai fungsi, ${ }^{24}$ di mana salah satunya adalah untuk menggambarkan Agustus sebagai model ideal bagi para pemimpin Romawi. ${ }^{25}$ Inskripsi RGDA sangat dikenal oleh para penulis Romawi (Seneca, Suetonius, dan Tacitus), ${ }^{26}$ dan tersirkulasi secara luas. Di provinsi Galatia ditemukan setidaknya tiga inskripsi RGDA, yakni di Ancyra (Latin and Yunani), di Pisidian Antioch (Latin), dan di Apollonia (Yunani). ${ }^{27}$ Karena Paulus pernah

24. Lihat Alison E. Cooley, Res Gestae Divi Augusti: Text, Translation, and Commentary (Cambridge: Cambridge University Press, 2009), 30.

25. Cooley, Res Gestae, 34.

26. Penerimaan RGDA tercatat di dalam tulisan Seneca, Apol.10.1; Suetonius, Aug.; Tacitus, Ann. 1.10.1-4. Lihat Cooley, Res Gestae, 50-51.

27. Cooley, Res Gestae, 6-18. 
mengunjungi Pisidian Antioch (lihat Kis. 13:14-52), sangat mungkin dia telah membaca inskripsi $R G D A$ yang terukir di kedua pilar gerbang masuk ke kuil imperial di kota ini.

Walaupun, kedua inskripsi ini tidak terletak di Makedonia, tulisan ini juga merepresentasikan opini publik terhadap kaisar Agustus di kawasan Timur Romawi pada masa Paulus. Karena provinsi Asia dan Galatia terletak tidak jauh dari provinsi Makedonia dan kota Filipi terletak di via Egnatia, propaganda imperial tentang Agustus ini sangat mudah tersosialisasikan kepada masyarakat Filipi. Dengan demikian, asumsi bahwa kedua diskursus publik tentang Agustus diketahui dengan baik oleh Paulus dan jemaat di Filipi cukuplah mendasar.

\section{Narasi Injil Kristus di Filipi 2:6-11}

Setelah membangun latar belakang imperial dari narasi Injil Kristus Yesus di Filipi 2:6-11, kini fokus pembahasan tertuju sepenuhnya kepada pembacaan perikop ini. Bagian ini akan mendemonstrasikan bahwa penggambaran Yesus Kristus di dalam Filipi 2:6-11 memang sengaja dikontraskan dengan penggambaran figur Agustus yang ada di dalam berbagai diskursus publik yang beredar di kekaisaran Romawi pada zaman Paulus, termasuk di kota Filipi. Di dalam pemberitaan injil imperial ini, Agustus digambarkan sebagai xúpros (Tuhan) dan $\sigma \omega \tau \eta \dot{\rho} \rho$ (Penyelamat) bagi dunia, karena dia adalah utusan dewa yang berhasil menyelamatkan dunia dari kehancuran dan menginagurasikan kedamaian dan kemakmuran di 
bawah kekaisaran Romawi. Oleh karena Kaisar Agustus adalah kabar baik bagi seluruh dunia, maka selayaknyalah semua bangsa sujud menyembah dia dan tunduk kepada pemerintahannya.

Merespons propaganda imperial Romawi mengenai Kaisar Agustus berikut dengan kultus penyembahannya, Paulus menarasikan kabar baik yang sesungguhnya bagi dunia di Filipi 2:611. Narasi ini, di satu sisi paralel dengan narasi Kaisar Agustus di dalam diskursus publik kekaisaran Romawi, di sisi lain mengkritisinya. Ini terlihat pada tabel di bawah ini: ${ }^{28}$

\begin{tabular}{|l|l|l|}
\hline Filipi 2:6-11 & \multicolumn{1}{|c|}{ Yesus Kristus } & \multicolumn{1}{c|}{ Kaisar Agustus } \\
\hline Ayat 6-8 & $\begin{array}{l}\text { sikap dan perbuatan } \\
\text { Kristus }\end{array}$ & $\begin{array}{l}\text { sikap dan perbuatan } \\
\text { Agustus }\end{array}$ \\
\hline Ayat 9 & $\begin{array}{l}\text { kebangkitan dan kenaikan } \\
\text { Kristus }\end{array}$ & apotheosis Agustus \\
\hline Ayat 10-11 & $\begin{array}{l}\text { penyembahan Kristus di } \\
\text { akhir zaman }\end{array}$ & $\begin{array}{l}\text { penyembahan Agustus } \\
\text { di masa itu }\end{array}$ \\
\hline
\end{tabular}

Dengan kerangka ini, kita menyoroti bagaimana narasi Kristus memberi kritik terhadap klaim imperial akan Kaisar Agustus.

Sikap and Perbuatan Sang Kúplos dan $\Sigma \omega \tau \eta \dot{\rho}$ Dunia (ay. 6-8)

Di dalam tulisannya (Aeneid 6.793), pujangga Romawi Virgil memuji Agustus sebagai divi genus (keturunan ilahi/dewa). Hal yang

28. Skema ini mengikuti pendapat Dieter Georgi, Theocacy, 76-77. Kontra Peter Oakes, From People to Letter, SNTSMS 110 (Cambridge: Cambridge University Press, 2001), 133. 
sama dilakukan oleh sejarawan Suetonius dalam tulisannya (Divus Augustus 94.4), di mana ia mencatat rumor berkenaan dengan kelahirannya bahwa Agustus memiliki ayah seorang dewa, yakni Apollo, dan ibu seorang manusia. Semasa hidupnya Agustus menyandang berbagai titel yang mengagungkan dirinya sebagai perwakilan ilahi di bumi, seperti divi filius, Agustus, Pontifex Maximus, dan Pater Patriare. Oleh karenanya, kepadanya

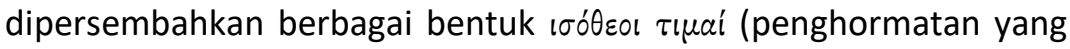
setara dengan Allah), seperti kuil, altar, festival, pertandingan, dan

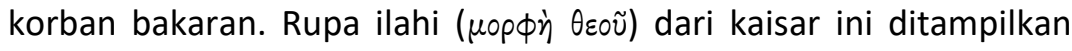
dalam bentuk patung, lukisan, dan koin yang tersebar di seluruh

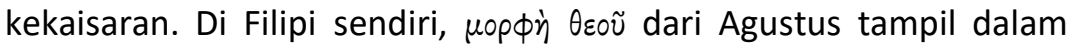
bentuk patung dirinya di Forum kota sebagaimana yang tercermin di koin kolonial Filipi. Di Forum kota inilah sang kaisar menerima

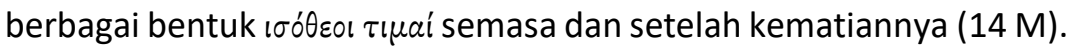

Dengan latar belakang ini, pernyataan di ayat 6 bahwa $\mu$ орфиे $\theta \varepsilon \circ \tilde{~ d a r i ~ Y e s u s ~ K r i s t u s ~ y a n g ~ m e r e f l e k s i k a n ~ s t a t u s ~ k e i l a h i a n-N y a ~(\tau o ̀ ~}$ Eĩval $\left.{ }^{\prime} \sigma \alpha \quad \theta \varepsilon \omega\right)$ sangat mungkin dibaca sebagai kritik terhadap propaganda imperial Romawi yang populer di kota Filipi bahwa Agustus adalah kaisar yang ilahi. Di dalam kerangka Monoteisme Yahudi, tantangan yang diberikan bukanlah tokoh manakah yang lebih superior, tetapi siapakah Ilahi yang sesungguhnya. Injil di Filipi 2:6-11 mengklaim bahwa tokoh ini tidak mungkin Agustus, tetapi Sang Kristus Yesus, dengan alasan bahwa tindakan di dalam ayat 6-8 
hanya dapat dilakukan oleh figur yang setara dengan Allah. Ayat-ayat ini mendeskripsikan tindakan Kristus yang bertolak belakang dengan tindakan Agustus semasa hidupnya.

Pertanyaan yang perlu dijawab adalah tindakan apa yang

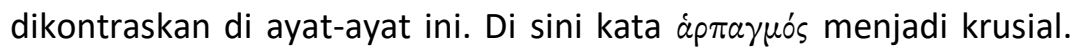
Amat disayangkan arti dari kata ini terus diperdebatkan hingga kini. Erik M. Heen berpendapat bahwa ayat 6 menggaungkan sikap kaisar yang berusaha merebut status ilahi. ${ }^{29}$ Dalam hal ini, penulis memiliki pandangan yang berbeda. Penyembahan universal kepada Kristus di ayat 10-11 mengklaim bahwa Yesus Kristus berstatus Ilahi. Karena di dalam pemikiran teologis Yahudi keilahian bersifat kekal, maka Kristus yang berstatus Ilahi di akhir zaman, pasti juga berstatus Ilahi sejak awalnya. Di dalam perspektif ini, áp $\pi a \gamma \mu o ́ s ~ s e b a i k n y a ~ d i p a h a m i$ sebagai sikap egosentris di dalam mengeksploitasi status ilahi, sebagaimana yang diusulkan oleh Hoover: "to regard something to be taken advantage of" atau "to regard something to be used for one's own advantage." 30 Dalam perspektif ini, kritik kepada Agustus terfokus pada bagaimana dia mengeksploitasi statusnya yang diklaim sebagai ilahi.

Berbagai diskursus publik di kekaisaran Romawi menekankan bahwa pelayanan Agustus yang terbesar adalah mengakhiri Roman Civil Wars yang identik dengan Zaman Besi dan membangun damai di

29. Erik M. Heen, "Phil 2:6-11," 125-54.

30. Roy Hoover, "The Harpagmos Enigma: A Philological Solusion," HTR 64 (1971): 95-119. 
muka bumi (Pax Romana) yang identik dengan Zaman Emas yang eskatologis. Melalui Agustus, dewa-dewi diklaim telah kembali ke dan memerintah di bumi, dan ini direspons oleh bumi dengan kesuburan dan kemakmuran. Semua propaganda ini mengagungkan Agustus sebagai tokoh besar yang menyejahterakan seluruh umat manusia. Sebagai koloni Romawi yang memiliki ikatan yang kuat dengan tokoh ini dan yang merepresentasikan kekuasaan Romawi di wilayah Makedonia, tentu saja diskursus publik di kota Filipi dipenuhi dengan berbagai eulogia yang merayakan kebesaran Agustus dan karya penyelamatannya atas dunia.

Hal yang perlu dicatat adalah bahwa status keilahian Agustus juga melegitimasi tindakannya dalam menghancurkan semua lawan politiknya untuk melanggengkan kekuasaannya, dan menjajah berbagai bangsa dan memperluas kekuasaan Romawi. Ideologi ini jelas terlihat pada dinding monumen Ara Pacis Augustae, di mana salah satu sisinya terukir gambar dewi Roma yang mengenakan kostum perang dengan berbagai harta rampasan perang dari bangsa yang ditaklukan terserak di hadapannya. Pada ukiran kuno Gema Augustae tampak gambar Agustus (bersama dewi Roma) duduk di atas takhta bagaikan dewa Jupiter yang sedang menerima corona civica. Ideologi yang tersirat adalah statusnya yang ilahi memberikan mandat kepada sang kaisar untuk menaklukkan bangsa-bangsa di dunia. Ini jelas terlukis di ukiran di bawahnya.

Seiring dengan ideologi imperialis ini, kisah keganasan dan penindasan Agustus ternyata beredar di berbagai komunitas yang 
merasakan penindasannya, dan ini tercuat ke luar di dalam tulisan dua sejarawan Romawi sesudah zaman Agustus. Suetonius, dalam Divus Augustus 13, menggambarkan kekejaman Agustus terhadap musuh yang juga adalah sesama Romawi sebagai berikut:

... He did not use his victory with moderation, but after sending Brutus' head to Rome, to be cast at the feet of Caesar's statue, he vented his spleen upon the most distinguished of his captives, not even sparing them insulting language. For instance, to one man who begged humbly for burial, he said to have replied: "the birds will soon settle than question." When two others, father and son, beg for his lives, he said to have bidden them cast lost or play mora, to decide which should be spared, and then to have looked on while both died, since the father was executed because he offered to die for his own son, and the latter thereupon took his own life. Because of this the rest, including Marcus Favonius, the well-known imitator of Cato, saluted Antony respectfully as Imperator, when they were led out in chains, but slashed Augustus to his face with foulest abuse. ${ }^{31}$

Sejarawan lain, Tatius, dalam Annales 1.10.1-3, juga mengkritik natur dari kedamaian yang dibangun Agustus sebagai berikut:

One the other side it was said: the pleas of filial duty and political necessity were but pretexts. It was lust of power which had prompted Augustus to attract the veterans by bribes, to collect an army while he was still stripling and without office, to tamper with the troops of the Counsel, and to affect sympathy with the Pompeian party. After that, by virtue of a decree of Senate, he had usurped the Praetorship, with its military and judicial power ... Peace, no doubt, had followed,

31. Diterjemahkan oleh John C. Rolfe (LCL). 
but it is a peace stained with blood: there had been disaster of Lollius and Varus abroad; at home, the executions of Varo, and Egnatius, and Iulius. Tacitus, Annals 1.10.1-332

Dengan latar belakang imperial ini, Filipi 2:6-8 mengklaim bahwa xúpios (Tuhan) yang sesungguhnya menggunakan status kesetaraan-Nya dengan Allah dengan cara yang bertolak belakang dengan tindakan Agustus. Jika Agustus mengeksploitasi statusnya yang diklaim ilahi dengan cara yang ganas dan untuk keagungan dirinya sendiri, Kristus justru mendemonstrasikan status keilahianNya dengan melepaskan kemuliaan-Nya agar dapat melayani manusia sebagai seorang hamba sampai titik kematian-Nya. Di dalam perspektif ini, Injil Kristus Yesus di dalam perikop ini membentuk pemahaman baru mengenai arti keilahian yang sesungguhnya: Dia yang setara dengan Allah tidak akan mengeksploitasi status keilahian-Nya untuk kepentingan diri sendiri dengan cara yang semena-mena, tetapi selalu siap melepaskan kemuliaan-Nya untuk melayani manusia. Injil ini jelas merupakan kritik keras terhadap konsep keilahian yang populer di masyarakat imperial Romawi, berikut dengan klaim mengenai keilahian Kaisar Agustus.

Selanjutnya, Filipi 2:6-8 juga mempertanyakan klaim imperial Romawi tentang keselamatan yang berpusat pada diri Agustus. Bagi Paulus, kedamaian dan keselamatan versi ini hanyalah sebuah ilusi. Di dalam Roma 8:19-23, ia bahkan menekankan bahwa hingga saat

32. The Annals of Tacitus: Books 1-4, diterjemahkan oleh George Gilbert Ramsay (London: John Murray, 1904), 88. Penekanan ditambahkan oleh penulis. 


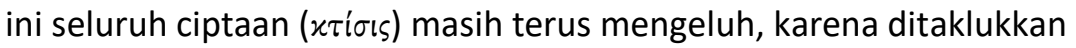

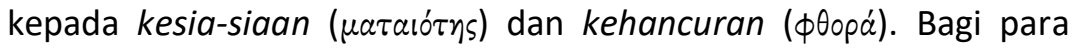

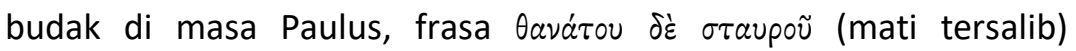
menggaungkan horor yang ditimbulkan Agustus yang mengeksekusi sekitar tiga puluh ribu budak yang melarikan diri semasa Roman Civil Wars (36 SM). ${ }^{33}$ Eksekusi ini dilakukan untuk memberi efek jera ke para budak, sehingga mereka tidak berani memberontak di kemudian hari. Injil keselamatan imperial dari Agustus jelas hanya diperuntukkan bagi kaum elit, karena bagi kaum papa, injil ini justru melahirkan penindasan dan penderitaan. Sebaliknya, Injil Kristus Yesus menekankan bahwa keselamatan yang sesungguhnya datang dari tokoh yang setara dengan Allah tetapi bersedia melayani layaknya seorang hamba. Dalam pelayanan-Nya, dia bahkan memberi diri hingga mati disalibkan. Di dalam Dialah kedamaian Allah yang sesungguhnya dapat dialami (Flp. 4:7).

Kebangkitan dan Kenaikan Sang Kúpıos dan $\Sigma \omega \tau \eta \dot{\rho}$ Dunia (ay. 9)

Pendewaan (apotheosis) Agustus oleh Senat Roma pada tahun $14 \mathrm{M}$ tidak berarti bahwa divus (dewa) Agustus sekadar produk politik

33. Peristiwa ini berhubungan dengan pemberontakan para budak dalam jumlah yang besar serta bergabungnya mereka dengan pasukan Sextus Pompey pada tahun 36 SM. Di RGDA Agustus mengklaim bahwa dia dengan murah hati menyerahkan sekitar 30 ribu budak kepada tuan mereka. Akan tetapi, Appian, (Bell. Civ. 5.13.131), Dio Cassius (49.12.4-5) melaporkan bahwa Agustus juga menyalibkan sekitar 6 ribu budak yang tuannya tidak teridentifikasi. 
dari kekaisaran Romawi, ${ }^{34}$ karena sebagian besar masyarakat Romawi memang sungguh mempercayainya sebagai ordinasi dari para dewa. Mengikuti kisah mitos apotheosis Romulus, sang pendiri Roma (lihat Livy, 1.16), tugas Senat Roma adalah meratifikasi status divus kaisar Romawi berdasarkan kesaksian yang teruji, bahwa arwah kaisar tidak turun ke Hades tetapi telah naik ke langit di mana para dewa berdiam. ${ }^{35}$ Pada kasus Agustus, sejarawan Suetonius (Aug. 99.4) mencatat: There was even an ex-praetor who took oath that he had seen the form of the Emperor, after he had reduced to ashes, on its way to heaven. ${ }^{36}$ Ratifikasi Senat Roma ini jelas mendukung klaim otoritas imperial Romawi bahwa dengan pencapaian dan "benefaksi" yang luar biasa bagi umat manusia, Agustus telah diterima ke dalam dunia para dewa di langit.

Dengan latar belakang ini, Injil Kristus di ayat 9 mengklaim bahwa bukan Agustus tetapi Yesus Kristuslah yang telah sangat

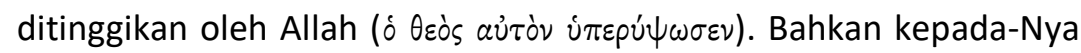

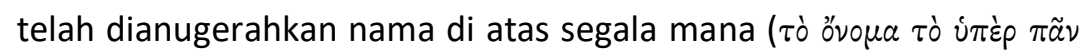
övoua) yang tak lain adalah Tetragrammaton (Yhwh), nama yang mengkonfirmasikan status keilahian-Nya. ${ }^{37}$ Yesus Kristus yang

34. Ittai Gradel, Emperor Worship and Roman Religion, Oxford Classical Monographs (Oxford: Clarendon, 2002), 288.

35. Gradel, Emperor Worship, 228; Price, "The Consecration of Roman Emperors" dalam Ritual of Royalty: Power and Ceremonial in Traditional Societies, 76.

36. Ittai Gradel, Emperor Worship, 295.

37. Markus Bockmuehl, The Epistle to the Philippians, Black's New Testament Commentary (London: Hendrickson, 1998), 142. 
berstatus "setara dengan Allah" sejak awalnya (ay. 6) telah dengan setia mengambil rupa seorang hamba untuk menjalankan karya keselamatan Allah bagi manusia (ay. 7-8). Oleh karenanya, Allah sendiri yang menobatkan Dia sebagai xúplos yang llahi tidak hanya atas seluruh umat manusia, tetapi bahkan atas seluruh alam semesta. Para murid Kristus, termasuk Paulus (1Kor. 15:3-8), menjadi saksi mata yang dapat dipercaya atas peristiwa penerimaan Kristus di sorga, di mana dia duduk di sebelah kanan Allah Bapa (Kis. 2:33; 5:31; 7:56; Rm. 8:34; Ef. 1:20; 1Ptr. 3:22).

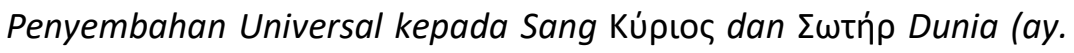
10-11)

Akhirnya, ayat 10-11 menekankan bahwa penyembahan universal di akhir zaman hanya akan tertuju kepada xúpıos Yesus Kristus. Pengakuan ini jelas bertentangan dengan berbagai propaganda mengenai dewa imperial Agustus di zaman Paulus. Menurut keyakinan Kristen, sebesar apa pun kekuasaan dan "benefaksi" dari Agustus, di mata para pengikut Kristus Yesus kaisar ini tidak mungkin menjadi xúpıos llahi, karena hanya Yesus Kristus yang dapat menduduki posisi ini. Walaupun kultus Agustus sangat termasyhur dan megah pada zaman itu, Paulus dan jemaat Kristus di Filipi meyakini bahwa di akhir zaman hanya kepada Kristuslah semua

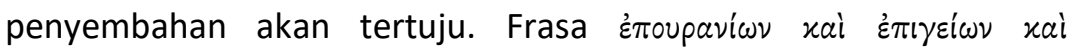




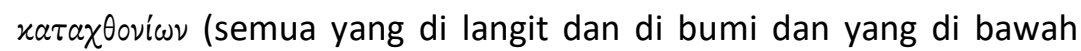
bumi) di ayat 10 menyiratkan bahwa kaisar Agustus juga akan turut di dalam prosesi penyembahan kolosal kepada Kristus di akhir zaman.

Selain itu, gambaran penyembahan Kristus di akhir zaman ini mengandung dimensi keselamatan. Filipi 2:10-11 bukanlah kutipan dari Yesaya 45:23-24 dan juga bukan sekadar alusi kepada ayat ini. Kedua ayat ini merupakan reworking atas visi keselamatan Yesaya. ${ }^{38}$ Untuk memahaminya, terjemahan Yesaya 45:21-25 LXX disajikan berikut ini:

(21) .... Bukankah Aku, TUHAN? Tidak ada yang lain, tidak ada Allah selain dari pada-Ku! Allah yang benar dan Juruselamat ( $\sigma \omega \tau \dot{n} \rho)$, tidak ada yang lain kecuali Aku! (22) Berpalinglah kepada-Ku dan biarkanlah dirimu diselamatkan $(\sigma \omega \theta \dot{\eta} \sigma \varepsilon \sigma \theta \varepsilon)$, hai ujung-ujung bumi! Sebab Akulah Allah dan tidak ada yang lain. (23) Demi Aku sendiri Aku telah bersumpah, dari mulut-Ku telah keluar kebenaran, suatu firman yang tidak dapat ditarik kembali: kepada-Ku semua lutut akan bertekuk, dan semua lidah akan memuji ${ }^{(24)}$ dengan berkata: Keadilan dan Kekuatan. Kepada-Nya akan datang dan mendapat malu, semua mereka yang menolak-Nya, ${ }^{(25)}$ tetapi seluruh keturunan Israel akan nyata benar dan akan bermegah di dalam TUHAN.

Di dalam konteks Yesaya 45, visi ini memanggil semua bangsa penyembah berhala (ay. 20) untuk bersama-sama bangsa Israel (ay.

38. Reworking ini dilakukan setidaknya di tiga area: (1) penyembahan kepada xúplos-YHWH dipahami sebagai penyembahan kepada xúplosKristus, (2) para penyembah dari semua suku-bangsa diekspansikan menjadi seluruh makhluk alam semesta, (3) masa penggenapan di zaman Kaisar Koresh di abad ke-6 SM berpindah ke zaman akhir (eskaton). 
25) berpaling dan memberikan diri mereka diselamatkan oleh Yhwh yang diklaim sebagai satu-satunya penyelamat ( $\sigma \omega \tau \eta \dot{\rho} \rho)$ yang benar (ay. 21-22). Kepastian akan keselamatan dari Yhwh diperkuat dengan komitmen-Nya untuk membuat semua bangsa menyembah dan mengakui kekuasaan-Nya yang absolut (ay. 23). Kaum yang menolak panggilan ini pada akhirnya tetap akan datang menyembah, tetapi akan dipermalukan atas ketidakpercayaan mereka (ay. 24). Dengan

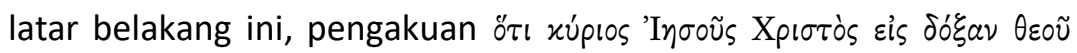

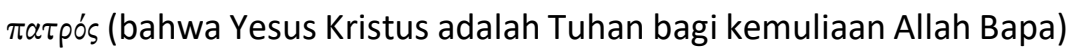
merupakan bagian dari keselamatan dari Yhwh yang diwujudkan di dalam Sang Mesias Yesus.

Nuansa keselamatan dari penyembahan akhir zaman ini diperkuat dengan pengajaran Paulus di Roma 10:9-10, bahwa

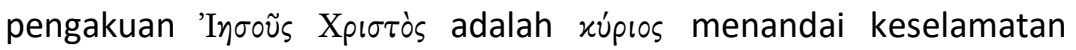
seseorang. Hanya saja, pujian pengakuan "Yesus Kristus adalah Tuhan" di Filipi 2:11 hadir di hadapan kursi pengadilan Allah di akhir

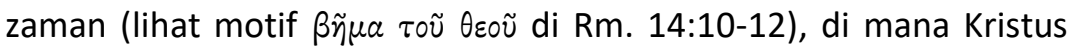
akan mengadili semua manusia. Ini berarti keselamatan bagi mereka, yang setia mengikuti dan menyembah Dia sebagai Tuhan Penyelamat ( $\sigma \omega \tau \dot{p} \rho-x u ́ p r o s)$, tetapi kehancuran bagi semua yang menolak, menentang dan meninggalkan Dia. Dengan pemahaman ini, penyembahan universal-eskatologis Kristus di Filipi 2:10-11 mempertanyakan klaim imperial akan keselamatan yang berpusat pada Agustus. Di tengah-tengah penderitaan jemaat di Filipi akibat 
penganiayaan dan tekanan kekuasan imperial Romawi, Paulus mengingatkan dan menguatkan mereka bahwa Penyelamat yang mereka nantikan, yakni Kristus Yesus (Flp. 3:20), pasti akan datang sebagai Tuhan yang berkuasa mutlak atas seluruh ciptaan (Flp. 1:1011). Pada saat itu keselamatan mereka di dalam Dia akan disempurnakan dan dirayakan (Flp. 3:21).

\section{Kesimpulan}

Injil Yesus Kristus yang dikisahkan di dalam Filipi 2:6-11 tidak hanya untuk mendorong jemaat Kristus di Filipi untuk meneladani perbuatan Kristus yang mulia (Flp. 2:1-4). Injil ini juga memanggil dan mendorong komunitas ini untuk terus berdiri teguh di dalam kesatuan demi iman mereka kepada Kristus di dalam menghadapi berbagai tekanan dari masyarakat imperial Romawi di kota ini. Narasi Injil ini mengukuhkan iman mereka bahwa penyembahan kepada Kristus yang eksklusif tetap merupakan pilihan tepat di tengah tekanan untuk berpartisipasi di dalam penyembahan dewa Kaisar Agustus yang populer di sana.

Injil ini mempresentasikan Yesus Kristus sebagai yang setara dengan Allah, dan yang mendemonstrasikan keilahian-Nya melalui tindakan menanggalkan kemuliaan-Nya dan melayani sebagai seorang hamba hingga mati disalibkan demi keselamatan umat manusia. Perbuatan-Nya tidak mungkin dilakukan oleh Agustus, walaupun banyak orang mengklaim dirinya sebagai yang ilahi. Itu sebabnya, hanya Kristuslah yang sangat ditinggikan dan dianugerahi 
oleh Allah dengan nama Tetragrammaton yang mengkonfirmasi diriNya sebagai llahi dan Penguasa atas seluruh semesta. Semua ciptaan, termasuk Kaisar Agustus, pada akhirnya akan menyembah dan mengakui bahwa Yesus Kristuslah Tuhan yang menyelamatkan. Dengan demikian, presentasi penyembahan Yesus Kristus di Filipi 2:10-11 jelas mengkritik ideologi imperial Romawi yang terpusat kepada dewa Kaisar Agustus, beserta dengan praktik penyembahan dirinya yang populer di kota Filipi saat itu.

\section{Bibliografi}

Barclay, John M. G. "Paul, Roman Religion and the Emperor: Mapping the Point of Conflict." Dalam Pauline Churches and Diaspora Jews, 345-387. Wissenchaftliche Untersuchungen zum Neuen Testament 275. Tübingen: Mohr Siebeck, 2011.

Bauer, W., F. Danker, W. Arndt, dan F. Gingrich, ed. Greek-English Lexicon of the New Testament and Other Early Christian Literature. Edisi ke-3. Chicago: University of Chicago Press, 2000.

Beck, Norman A. Anti-Roman Cryptograms in the New Testament: Hidden Transcripts of Hope and Liberation. Edisi revisi, SBL 127. New York: Peter Lang, 2010.

Bockmuehl, Markus. The Epistle to the Philippians. Black's New Testament Commentary. London: Hendrickson, 1998.

Bryan, Christopher. Render to Caesar: Jesus, the Early Church, and Roman Superpower. Oxford: Oxford University Press, 2005.

Cassidy, Richard J. Paul in Chains: Roman Imprisonment and the Letters of St. Paul. New York: The Crossroad, 2001.

Cohick, Lynn H. "Philippians and Empire: Paul's Engagement with Imperialism and the Imperial Cult." Dalam Jesus is Lord and Caesar is not: Evaluating Empire in New Testament. Downers Grove: IVP Academic, 2013.

Collins, Adela Yarbro. "The Worship of Jesus and the Imperial Cult." Dalam The Jewish Roots of Christological Monotheism: Papers 
from the St. Andrews Conference on the Historical Origins of the Worship of Jesus, SJSJ 63. Leiden: Brill, 1999.

Cooley, Alison E. Res Gestae Divi Augusti: Text, Translation, and Commentary. Cambridge: Cambridge University Press, 2009.

Fee, Gordon D. Paul's Letter to the Philippians. New International Commentary on the New Testament. Grand Rapids: Eerdmans, 1995.

Foerster, "xúplos," Theological Dictionary of the New Testament 3:1054-1058.

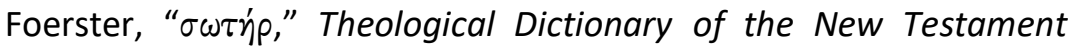
7:1010-1012.

Georgi, Dieter. Theocracy in Paul's Praxis and Theology, Diterjemahkan oleh D. E. Green. Minneapolis: Fortress, 1991.

Gorman, Michael J. Inhabiting the Cruciform God: Kenosis, Justification, and Theosis in Paul's Narrative Soteriology. Grand Rapids: Eerdmans, 2009.

Gradel, Ittai. Emperor Worship and Roman Religion. Oxford Classical Monographs. Oxford: Clarendon, 2002.

Hays, Richard B. The Faith of Jesus Christ: the Narrative Substructure of Galatians 3:1-4:11. Edisi ke-2. Grand Rapids: Eerdmans, 1997.

Heen, Erik M. "Phil 2:6-11 and Resistance to Local Timocratic Rule: Isa theo and the Cult of the Emperor in the East." Dalam Paul and the Roman Imperial Order. Harrisburg: Trinity International, 2004.

Hellerman, Joseph H. Reconstructing Honor in Roman Philippi: Carmen Christi as Cursus Pudorum. Society for New Testament Studies Monograph Series 132. Cambridge: Cambridge University Press, 2005.

Hoover, Roy W. "The Harpagmos Enigma: A Philological Solution." Harvard Theological Review 64 (1971): 95-119.

Dunn, James D. G. The Theology of Paul the Apostle. Grand Rapids: Eerdmans, 1998.

Kim, Seyoon. Christ and Caesar: The Gospel and the Roman Empire in the Writings of Paul and Luke. Grand Rapids: Eerdman, 2008. 
Martin, Ralph P. dan Gerald F. Hawthorne. Philippians. Revised Edition. Word Biblical Commentary. - : Nelson Reference \& Electronic, 2004.

Nagata, Takeshi "Philippians 2:5-11: A Case Study in the Contextual Shaping of Early Christianity." Disertasi PhD. Princeton: Princeton Theological Seminary, 1981.

Oakes, Peter. "Re-mapping the Universe," Journal for the Study of the New Testament 27/3 (2005): 301-22; . Philippians: from People to Letter. Society for New Testament Studies Monograph Series 110. Cambridge: Cambridge University Press, 2001.

Pilhofer, Peter. Philippi Band 2: Katalog der Inschriften von Philippi.

2. Wissenchaftliche Untersuchungen zum Neuen Testament 119. Tübingen: Mohr Siebeck, 2009.

Porter, Stanley E. "Paul Confronts Caesar with the Good News." Dalam Empire in the New Testament. Eugene: Wipf \& Stock, 2011.

Powell, Mark Allan. What is Narrative Criticism? Minneapolis: Fortress, 1990.

Price, Simon. "The Consecration of Roman Emperors." Dalam Ritual of Royalty: Power and Ceremonial in Traditional Societies. Editor David Cannadine dan Simon Price. Cambridge: Cambridge University Press, 1992.

Seeley, David. "The Background of the Philippians Hymn (2:6-11)," Journal of Higher Criticism 1 Fall (1994): 49-72;

Stanton, Graham. The Gospels and Jesus. Edisi ke-2. New York: Oxford University Press, 2002.

Tacitus, The Annals of Tacitus: Books 1-4. Diterjemahkan oleh George Gilbert Ramsay. London: John Murray, 1904.

Wright, N. T. "Paul's Gospel and Caesar's Empire." Dalam Paul and Politics: Ekklesia, Israel, Imperium, Interpretation. Editor Richard A. Horsley. Harrisburg: Trinity International, 2000.

Wright, N. T. Paul and the Faithfulness of God. Minneapolis; Fortress, 2013. 